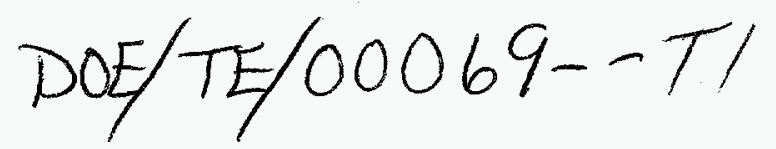

\title{
Final Report \\ Laser Sampling System for an Inductively-Coupled Atomic Emission Spectrometer
}

DOE Grant No.: DE-FG03-95TE00069

Contracting Officer

Gerald R. Acock

Contract Specialist

DOE Oakland Operations Office

1301 Clay Street, Room $700 \mathrm{~N}$

Oakland, CA 94612-5208

\section{Project Director:}

John Moore,

Department of Metallurgy and Material Science,

Colorado School of Mines, Golden CO 80401.

DSTRIBUTION OF THIS DOCUMENT IS UMLMTEO \& MASTER

February 15, 1998 


\section{DISCLAIMER}

This report was prepared as an account of work sponsored by an agency of the United States Government. Neither the United States Government nor any agency thereof, nor any of their employees, makes any warranty, express or implied, or assumes any legal liability or responsibility for the accuracy, completeness, or usefulness of any information, apparatus, product, or process disclosed, or represents that its use would not infringe privately owned rights. Reference herein to any specific commercial product, process, or service by trade name, trademark, manufacturer, or otherwise does not necessarily constitute or imply its endorsement, recommendation, or favoring by the United States Government or any agency thereof. The views and opinions of authors expressed herein do not necessarily state or reflect those of the United States Government or any agency thereof. 


\section{DISCLAIMER}

Portions of this document may be illegible electronic image products. Images are produced from the best available original document. 


\section{Initial Technical Report}

A. Equipment Purchased, Date of Installation, Acquisition Costs, Installation Costs 1. Model 320 Perkin Elmer YAG Laser Sampler; Installed on August 1, 1995. Acquisition Cost: $\$ 68,000$ for instrument in addition 2 years of maintenance $\$ 30,000$. Installation Cost: $\$ 2,000$.

2. DEC 486-66 MHz computer; installed on January 5, 1996. Acquisition Cost: $\$ 8,100$. Installation Cost: $\$ 000$.

3. Computer Resources $486-200 \mathrm{MHz}$ computer; installed on September 1, 1996. Acquisition Cost: $\$ 4,200$. Installation Cost: $\$ 000$.

4. Perkin Elmer Autosystem Gas Chromatograph with thermal conductivity detector; installed on February 1, 1997. Acquisition Cost: \$11,100; Installation Cost: \$ 1,000 .

B. Installation and Operating Use Experience

This laser samplinz system was attached to a Perkin Elmer Optima 3000 inductively-coupled plasma, atomic emission spectrometer that was already installed and operating in the Chemistry and Geochemistry Department at the Colorado School of Mines. The Optima 3000 was purchased nine months earlier with an equipment grant from the Geosciences Section of NSF. The use of the spectrometer has been highly successful. Graduate students and faculty from at least four different departments across the CSM campus have used the instrument. The final report to NSF is appended to this final report.

Making the laser sampler operational occurred with no difficulties. However, it was soon found that different material ablated and vaporized at different rates. This implies that, for quantitative results, solid standards that are close in composition to the samples would have to be used. As a consequence, qualitative results could be generated on a routine basis but for quantitative results, a project had to be committed to extensive analytical development.

Fortunately, a project arose that has fit in well with the objectives of the DOE materials science guidelines. This is described in the Technical Report section of this document.

\section{Technical Report}

A. Status and Use of the Laser Sampler

The laser sampler is used regularly for sampling steels. The project that primarily uses the laser sampler is "Development of New Methods for Determining Hydrogen Distribution in Welded Steel". Appended to this report are four documents describing this project:

1. A paper published at the Welding Research Institute in Australia on the problem of hydrogen in the weldments of high strength steels. 
2. The 1996 annual report to the Department of Army on this project.

3. An author application form for presentation of a paper at the Annual American Welding Society Convention in Detroit, April 27-30, 1998.

4. The 1997 annual report to the Department of Army on this project.

Originally, it was assumed that the hydrogen analysis would be done by optical emission spectroscopy. However, because of hydrogen contamination from water vapor and air entrained in the argon plasma, it was found that detection of hydrogen in steel by atomic spectroscopy was quite difficult. On the other hand, laser sampling of the base metal and weld is still a valuable tool. Consequently, the laser was attached to a gas chromatograph and the hydrogen is detected using a thermal conductivity detector. Currently, this is the primary use for the laser sampler.

\section{B. New Research Projects Undertaken Using the Laser Sampler}

The primary new research project undertaken using the laser sampler was the one described above: "Development of New Methods for Determining Hydrogen Distribution in Welded Steel". As described in the paper in Appendix II, this project has great technological interest because hydrogen embrittlement along welds is a major cause of the failure of high strength steel structures. High pressure boilers, submarines, pipelines, and bridges all use high strength steel with welds. Analysis of hydrogen in these structures is extremely difficult because the abundance of hydrogen in high strength steel is very low (about 1 part per million). The analysis has to be made in-situ to determine how the relative abundance of hydrogen changes from the base metal to the heat affected zone and into the weld. In addition, diffusion can result in movement of the hydrogen from the weld zone in a matter of hours.

At this time, laser ablation of the steel sample coupled with gas chromatography using thermal conductivity detection has given us preliminary confirmation of differences in hydrogen abundance in the weldment samples. Such work could not be done without the immediate availability of the laser sampler provided by this grant

\section{Financial Data on Operation and Maintenance of the Laser Sampler.}

Because Coolbaugh Hall, the building that houses the research laboratories of the Chemistry and Geochemistry Department, was renovated and expanded in 1994, most of the utilities needed for installation of the laser sampler were readily available. Installation was trouble free and only required providing an isolated 220 volt power line. Also, two computers were needed to complete the facility: one to control the beam position of the laser, and another to assist in running data programs used to process the analytical results. These computers are listed in the Initial Technical Report.

The sampler requires extensive use of argon to isolate the ablation area from atmospheric gases and to carry the aerosols and vapors into the detection device. Consequently, about $\$ 6,000$ was spent on setting up gas lines and purchasing argon, hydrogen, and nitrogen. This continuous expense will be met in the future through the establishment of an instrument fund that will charge projects a reasonable fee for use of the instrument. 
Because it was strongly advised in the proposal guidelines that such be done, a maintenance contract was taken out on the laser sampler. This amounted to $\$ 30,000$ for the second and third years of use. To date, the laser has been trouble free. It has required service only once. Consequently, in this case such a service contract was probably not needed.

When it was decided to attach the laser to a gas chromatograph, a special chromatograph and gas sampling equipment was purchased to make this change.

D. Faculty and Graduate Student use of the Equipment

As stated in the NSF report, faculty and graduate student use of the Optima 3000 ICP has been tremendous. It is probably the most used piece of analytical equipment on the CSM campus.

Because laser sampling is more specialized and standards specific to the sample are required, its use is quite a bit less. Certainly the heaviest use is with the hydrogen project described in sections II-A and II-B. On this project, two faculty members and three graduate students are using the instrument.

In addition to this project, one faculty member and graduate student have used the sampler to measure boron abundances in pegmatite rocks. In this case, analysis by XRF is out of the question because boron is such a light element.

The laser sampler is also used for qualitative analyses of solid samples. Using this mode, four graduate students and two faculty members have had samples analyzed by the spectroscopy laboratory.

\section{E. Important Experimental Results}

Definitely, the important result has been that through the use of this laser sampler and using gas chromatography detection, we have been able to determine the relative abundance of hydrogen in-situ across the weld of a high strength steel. These results will be published in the proceedings of 1998 Annual Meeting of the American Welding Society.

Our ultimate objective is to be able to construct a simple measurement system that can be used to measure hydrogen across welds at the place that the welds are fabricated (that is, in the case of the Navy, the shipyard). It may not be the case that laser sampling is chosen as the actual measurement system. However, it does serve as our primary method of sampling during the development stages. Analysis of low abundances of hydrogen is difficult under any circumstances. Currently, we are trying to develop a system that will easily react with the hydrogen and can be used detected to determine the relative amounts of hydrogen across the weld zone.

The problem is a fascinating analytical challenge that carries great practical consequences. 
APPENDICES

Appendix 1: Spectrometer for the Geochemistry Program." Final Project Report to the NSF Earth Sciences Division.

Appendix II:

Appendix III: Steel Weldments through Advanced Hydrogen Content Analysis." 1996 Annual Report to the U.S. Army Research Office.

Appendix IV: "Methods for Determination of Hydrogen Distribution in High Strength Steel Welds." Author Application Form for the 1998 Annual Convention of the American Welding Society.

Appendix V: $\quad$ "Hydrogen Damage Susceptibility Assessment for High Strength Steel Weldments through Advanced Hydrogen Content Analysis." 1997 Annual Report to the U.C Army Research Office.

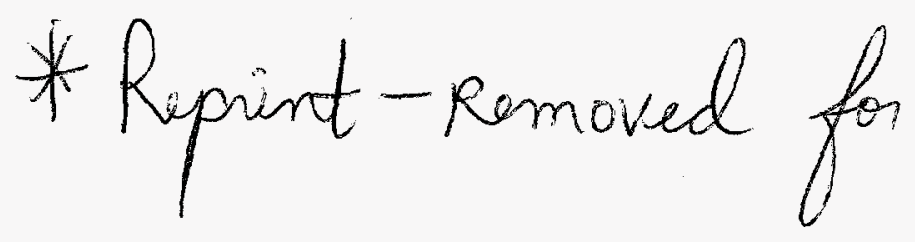




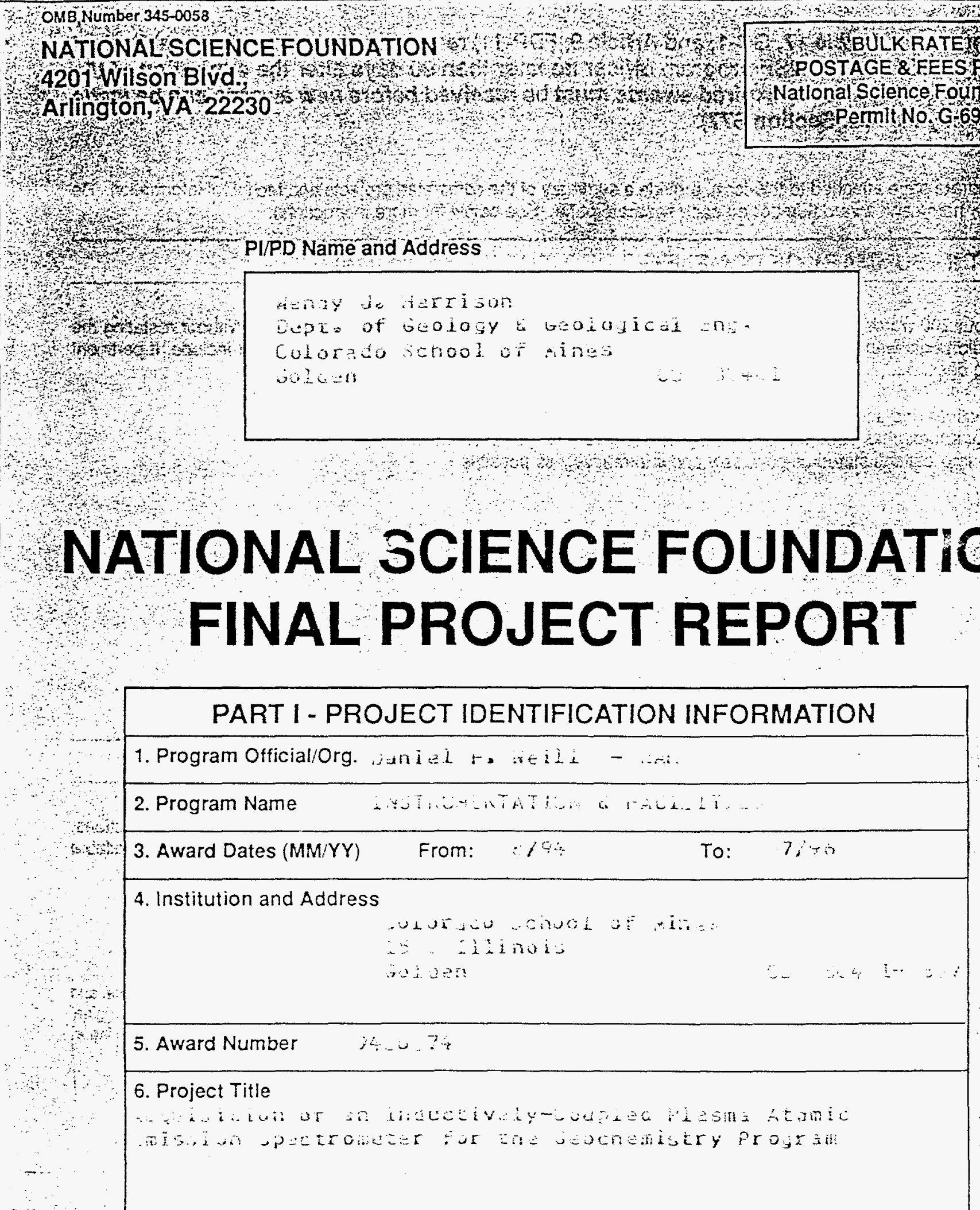

* You are encouraged to subat your finaloproject report electronically ** through the MSF fastlane hore page (wwifastlane insf ovi):

This Packet Contains NSF Form $98 \mathrm{~A}$ And 1 Return Envelope 
S*F Grant Conditions (Article 17, GC-1, and Article 9, FDP-11) require submission of a Final Project eport (NSF Form 98A) to the NSF program officer no later than 90 days alter the expiration of the ward. Final Project Reports for expired awards must be received before new awards can be made VSF Grants Policy Manual Section 677).

elow, or on a separate page attached to this form, provide a summary of the completed projects and technical information. Be sre to include your name and award number on each separate page. See below for more instructions.

PART II - SUMMARY OF COMPLETED PROJECT (for public use)

ne summary (about 200 words) must be self-contained and intelligible to a scientifically literate reader. Without restating the roject title, it should begin with a topic sentence stating the project's major thesis. The summary should include, if pertinent s the pruject being described, the following items:

The primary objectives and scope of the project

The techniques or approaches used only to the degree necessary for comprehension

The findings and implications stated as concisely and informatively as possible

PART III - TECHNICAL INFORMATION (for program management use)

ist references to publications resulting from this award and briefly describe primary data, samples, physical collections, iventions, software, etc. created or gathered in the course of the research and, if appropriate, how they are being made available o the research community. Provide the NSF Invention Disclosure number for any invention.

certify to the best of my knowledge (1) the statements herein (excluding scientific hypotheses and scientific opinion) are true and complete, and 2) the text and graphics in this report as well as any accompanying publications or other documents, unless otherwise indicated, are the original vork of the signatories or of individuals working under their supervision. I understand that willfully making a false statement or concealing a naterial fact in this report or any other communication submitted to NSF is a criminal offense (U.S. Code, Title 18, Section 1001).
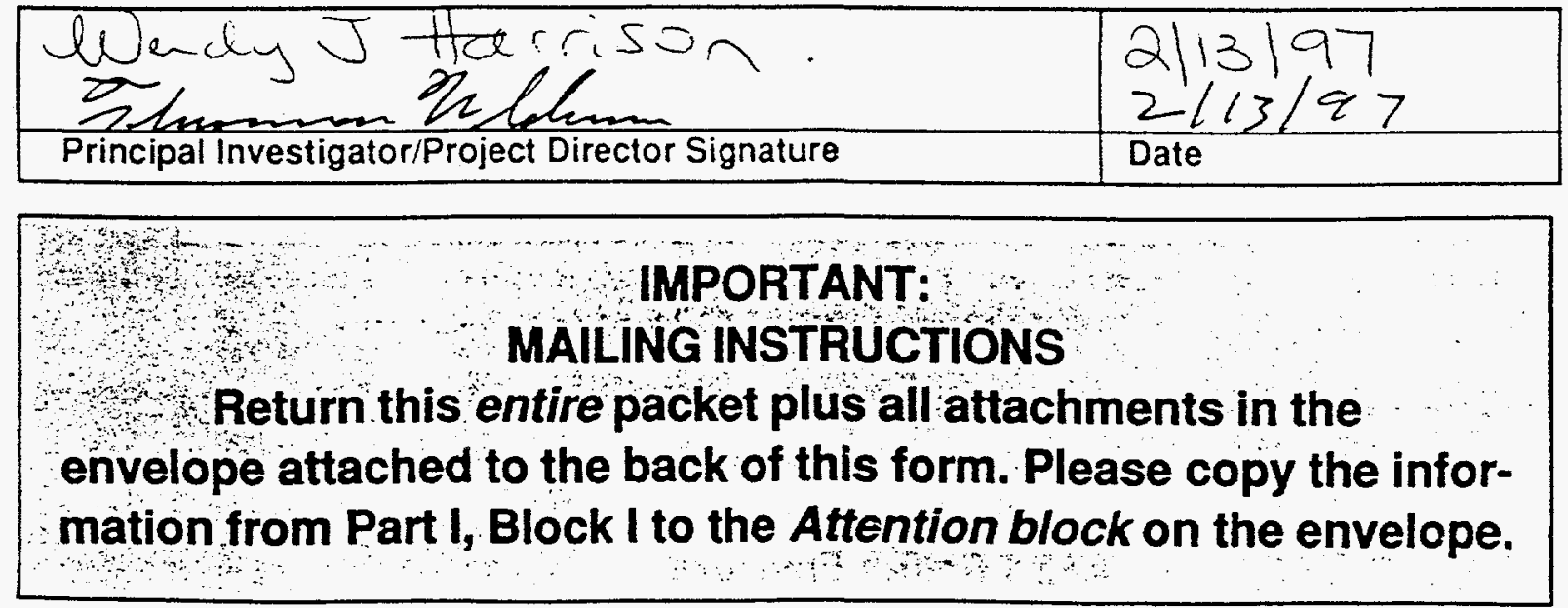

NSF Form 98 A (Rev. 8/93) 


\section{PART IV -- FINAL PROJECT REPORT -- SUMMARY DATA ON PROJECT PERSONNEL}

(To be submitted to cognizant Program Officer upon completion of project)

The data requested belnw are important for the development of a statistical profile on the personnel supported by Federal grants. The information on this part is solicited in resonse to Public Law $99-383$ and 42 USC 1885C. All information provided will be treated as confidential and will be safeguarded in accordance with the provisions of the Privacy Act of 1974. You should submit a single copy of this part with each final project report. However, submission of the requested information is not mandatory and is not a precondition of future award(s). Check the "Decline to Provide Information" box below if you do not wish to provide the nformation.

Please enter the numbers of individuals supported under this grant.

Do not enter information for individuals working less than 40 hours in any calendar year.

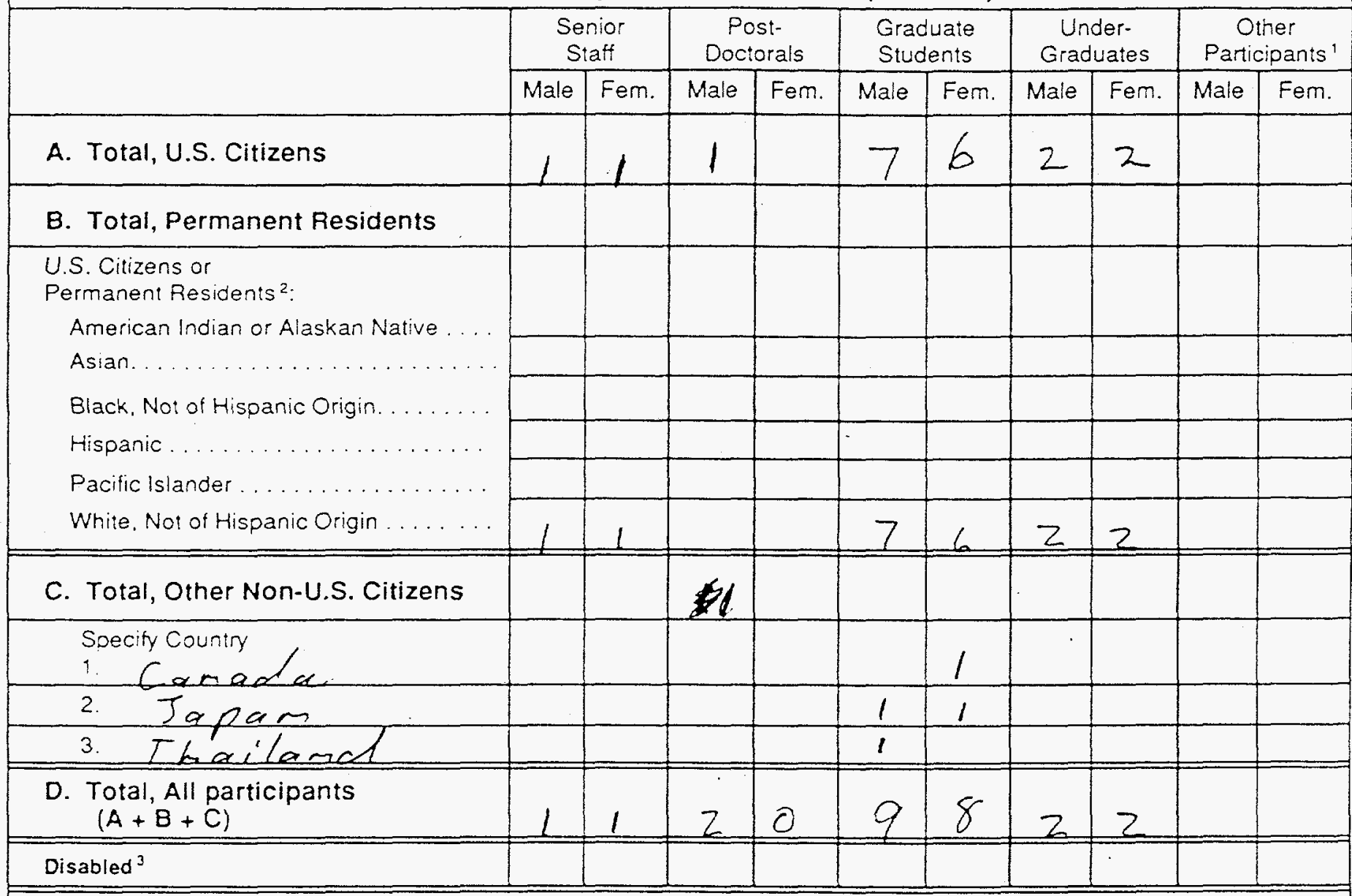

Decline to Provide Information: Check box if you do not wish to provide this information (you are still required to return this page along with Parts 1 - 111 ).

'Cateyory includes, for example, college and precollege teachers, conterence and workshop participants.

${ }^{2}$ Use the category that best describes the ethnic/racial status to all U.S. Citizens and Non-citizens with Permanent Residency. (If more than one category applies, use the one category that most closely reflects the person's recognition in the community.)

${ }^{3}$ A person having a physical or mental impairment that substantially limits one or more major life activities: who has a record of such impairment: or who is regarded as having such impairment. (Oisabled individuals also should be counted under the appropriate ethnicracial group unless they are classified as "Other Non-U.S. Citizens.")

AMERICAN INDIAN OR ALASKAN NATIVE: A person having origins in any of the original peoples of North America and who maintains cultural identification through tribal affiliation or community recognition.

ASIAN: A person having origins in any of the original peoples of East Asia, Southeast Asia or the Indian subcontinent. This area includes, for example. China, india, Indonesia, Japan, Korea and Vietnam.

BLACK, NOT OF HISPANIC ORIGIN: A person having origins in any of the black racial groups of Africa.

HISPANIC: A person of Mexican, Puerto Rican, Cuban, Central or South American or other Spanish culture or origin, regardless of race.

PACIFIC ISLANDER: A person having origins in any of the original peoples of Hawaii; the U.S. Pacitic territories of Guam, American Samoa, and the Northern Marinas; the U.S. Trust Territory of Palau; the islands of Micronesia and Melanesia: or the Philippines.

WHITE, NOT OF HISPANIC ORIGIN: A person having origins in any of the original peoples of Europe. North Airica, or the Middle East. 


\section{PART II SUMMARY OF COMPLETED PROJECT}

Because of the strong environmental and petrochemical emphasis within the interdisciplinary geochemistry program at CSM, education of students on the operation and use of an inductively coupled plasma (ICP), atomic emission spectrometer (AES) is essential. An additional educational objective is liberal access to instruments for research projects. This grant allowed purchase of an ICP-AES and implementation of these education and research objectives. Success of the project is measured by the fact that over 40 graduate students and 15 undergraduates have had hands-on laboratory education on the instrument. On a research basis, the instrument has been used in over 20 research projects in 5 different departments. In all of the projects, the students were directly involved in operating the instruments. Success was achieved because the ICP-AES is the first of a generation of user-friendly instruments. Ease of use was so good that undergraduates were put in charge of day-to-day use of the instrument and in aiding the analytical needs of research personnel.

\section{PART III - TECHNICAL INFORMATION}

Listed below are the theses, publications, published abstracts, completion reports, and seminars that used results generated by the ICP-AES.

\section{RESEARCH ACTIVITIES INVOLVING THE PERKIN-ELMER OPTIMA 300 ICP-AES, 1995 - 1936}

\section{Theses and dissertations completed}

Taufen, P.M., 1996, A geochemical study of groundwaters and stream waters at two mineralized sites in the Noranda district, Quebec-Application to mineral prospecting, mine development, and environmental remediation, $\mathrm{T}-4602, \mathrm{PhD}$. Geochemistry, 1996.

Kelsey, P.D., 1996, Weathering of Cu-Ni mineralized mine tailings from the Duluth complex, Minnesota, T- 4784, M.S. Geochemistry, 1996.

Abdulrahman Al-Awar "Stratigraphy, dolomitization, and anhydritization of the Upper Devonian Nisku Formation at Joffre Field, in Alberta, Canada", Ph.D., 1996.

Tomoko Kito, "The Evaluation and Characterization of Acid Catalysts Used in an On-Board Diethyl Ether Generator for Cold-Start Assistance of an Ethanol Fueled Vehicle", Ph.D. Dissertation, Colorado School of Mines, 1996.

Sexsmith, K.S. Geological, hydrological and chemical controls on $222 \mathrm{Rn}$ variability in groundwater. Master's Thesis, Division of Environmental Science and Engineering, Colorado School of Mines, Golden, CO, 1996. 199 p.

\section{Published Papers}

Wildeman, T. R., Kelsey, P. D., and Lapakko, K., 1995, Relating sulfate generation to a model of physical flow through waste rock piles: Attempts and consequences. In: 
Proceedings of the 12th annual meeting of ASSMR, G. E. Schuman and G. F. Vance Eds., ASSMR, Princeton WV, pp. 539-546.

Kelsey, P.D., R.W. Klusman, K.A. Lapakko, 1996, An investigation of the metal adsorption properties of ferric hydroxide formed from the weathering of a stockpile in the Duluth Complex, Minnesota. Proc. Amer. Soc. Surface Mining and Reclamation, pp. 671-680.

Mitchell, K.G., and Wildeman, T.R. 1996. "Solubility of Fe (III) and Al in AMD by modelling and experiment". In: Proceedings of 13th Annual Meeting of American Society for Surface Mining and Reclamation, pp. 681-689. May 18-23, 1996, Knoxville, TN.

Trainor, T. P., S. Fleisher, T. R. Wildeman, R. J. Goldfarb, and C. S. Huber, 1996, Environmental geochemistry of the McKinley Lake ;gold mining district, Chugach National Forest, Alaska. In, geologic Studies in Alaska by the U. S. Geological Survey, 1994, U. S. Geological Survey Bulletin 2152, pp. 47-58.

\footnotetext{
Abstracts Published

Mitchell, K. G., and T. R. Wildeman, Solubility of Fe (III) and Al in AMD by modelling and Experiment, 209th National Meeting of the American Chemical Society, April, 1995, Anaheim, CA
}

Kelsey, P.D., R.W. Klusman, K.A. Lapakko, 1996, An investigation of the metal adsorption properties of ferric hydroxide formed from the weathering of a stockpile in the Duluth Complex, Minnesota. Proc. Amer. Soc. Surface Mining and Reclamation, Knoxville, TN, May 18-23, 1996.

Kelsey, P.D., and R.W. Klusman, 1996, Weathering of copper-nickel mineralized mine tailings from the Duluth complex, Minnesota and the effect on water quality. 13th Rocky Mountain Regional Meeting, American Chemical Society, Denver, CO, June 9-12, 1996.

Al-Bastaki, A., Humphrey, J. D., and Moore, C. H., 1996, Stratigraphic and diagenetic controls on the distribution of reservoir properties in the Devonian Nisku Formation at Joffre Field, Alberta; Amer. Assoc. Petrol. Geol. Abs., v. 5, p. 2-3.

Al-Awar, A., Humphrey, J. D., and Moore, C. H., 1996, Geochemical constraints on dolomitization and anhydritization of the Devonian Nisku Fm. at Joffre Field, Alberta; Geol. Soc. America Abstracts with Programs, v. 28, p. A-36.

Sare, V. P., and Humphrey, J. D., 1996, Sediment-water interaction in Holocene carbonate islands, San Blas Archipelago, Panama; Geol. Soc. America Abstracts with Programs, v. 28, p. A-338.

Suwanakijboriharn, S and Harrison W.J., 1996, Solubility of iron (II) carbonate at temperatures between 25 and $700 \mathrm{C}$ and $1 \mathrm{~atm}$ total pressure: Geological Society of America Abstracts with Program, Denver CO 1996. 
Klett, T.R., Harrison, W.J., and Wendlandt, R.F., 1996, Effects of carbon dioxide on sandstone reservoir quality: AAPG Annual Meeting, San Diego, 1996.

T. R. Wildeman, and J. R. Gormley, History and recent advances in passive treatment for metal mine drainages, 2nd International Gold Symposium, Lima, Peru, May, 1996.

T. R. Wildeman, and K. G. Mitchell, Solubility of Fe(III) and Al in AMD by Modelling and Experiment, 13th Annual National Meeting of the American Society of Surface Mining and Reclamation, Knoxville, TN, May 1996.

J. W. Dinkel, R. M. Smith, and T. R. Wildeman, Treatment assessment for mine drainages in Colorado, 13th Rocky Mountain Regional Meeting of the American Chemical Society, Lakewood, CO June, 1996.

\section{Submitted Journal Articles}

Ozawa, Toshisuke, R.R.H. Cohen, R.W. Klusman, 1996, Biogeochemistry of arsenic and chromium in a wet substrate, anaerobic bioreactor dominated by sulfatereducing bacteria. Environmental Research, In Revision.

T. Kito, D. Pacas, S. Selim, and S.W. Cowley, "Properties of an Ethanol, Diethyl Ether, and Water Ternary Fuel Mixture for Cold-Start Assistance of an Ethanol Fueled Vehicle", submitted to I\&EC Fundamentals, February 1997.

T. Kito and S.W. Cowley, "Evaluation, Kinetics, and Mechanism of Selective Ethanol Dehydration to Diethyl Ether over Solid Acid Catalysts" to be submitted to J. Catalysis, March 1997.

Characterization of Ethanol Dehydration Catalysts by XRD, RDF, Solid State NMR, XPS and TPD, to be submitted to Langmuir, March 1997.

\section{Reports}

"Herstellung und Charakterisierung eines Gold-Sorbenten mit Silica und Lanthana-modifiezierten Silica als Traeger", Dipom Arbeit von Anja Bauer, Fachbereich Chemieingenieurwesen, Abteilung Steinfurt, Fachhochschule Muenster, 1996.

Klett, T.R., Wendlandt, R.F., and Harrison W.J., (1996). Effects of aqueous carbon dioxide on reservoir quality of carbonate cemented sandstones: Final report: U.S. Geological Survey.

Harrison, W.J., Wendlandt, R.F., Ernstberger, J., Simon, J.I. and Chastain, E.A., (1996). Phase I Results: Acid buffering capacity and metals mobility study, San Luis Valley agricultural soils, Alamosa, Colorado; Phase I Report, Colorado Department of Public Health and the Environment and the Environmental Protection Agency, 113p.

Paschke, S.S. and Harrison W.J., (1996). Characterization of Iron Transport through a Natural Wetland Impacted by Acid Mine Drainage, Final Report, Colorado Water Resources Research Institute. 
Sanpawanitchakit, C., L. Figueroa and B.D. Honeyman. (1996) Partitioning of metals in secondary wastewater effluent. Report for the Edna Baily Sussman

Foundation.

\section{Proposals Funded}

Title: Acid Buffering Capacity and Metals Mobility in Agricultural

Soils, San Luis Valley. Date: 3/96 Funding Level: \$122,386 Agency: Colorado

Department of Public Health and Environment Co-workers: R.F. Wendlandt (PI)

Duration: 3/96-12/97

Title: Characterization of Iron Transport through a Natural Wetland Impacted by Acid Mine Drainage Date: 7/95 Funding Level: \$15,000 Agency: Colorado Water Resources Research Institute Co-workers: D. Macalady and S.S. Paschke Duration: ended 9/96

\section{Presentations Made}

Wildeman, T. R., What is Geochemical Engineering?, Montana Tech of the U. of Montana, Butte MT, December, 1995.

Wildeman, T. R., and P. D. Kelsey, Use of the ICP-AES in Materials Science Research, CSM Materials Science Seminar, April, 1995.

Harrison W.J., and Paschke, S.S., (1996). Reactive transport modeling of water-rock interaction and possible diagenetic applications to BasinMod: BasinMod User Group Meeting, Feb.1-2, 1996, Platte River Associates, Inc., Denver, Co.

Harrison W.J. and Wendlandt, R.F., (1996). Summitville Technical Advisory Group: "Acid buffering capacity and metals mobility study, San Luis Valley agricultural soils", Alamosa, November 14, 1996.

\section{PART IV - NOTES TO THE PARTICIPANT TABLE}

1. The data sheet lists the participants that used the ICP-AES on a research basis for over 40 hours per year. Another 40 graduate students and 15 undergraduates have had educational access to the instrument.

2. Three of the undergraduate students were paid by funds from institutional funds that acted as matching money for the grant. Such an arrangement was possible because Perkin-Elmer provided an extra purchase discount for the instrument. A total of $\$ 8,000$ was used for undergraduate student wages. 


\section{REPORT DOCUMENTATION PAGE}

Form Approved

OMBNO.0704-0188

Putic reporting burden for this collection of inlomation is esimated to average i hout per response, induding the time for reviewing instructions, searehing existing data sourtes gathering and maintaining the data neoded, and completing and reviewing the collection of intormation. Send conment regarding this burden estimates or any other aspect of ihis Davis Highway. Suite 1204. Artingion, VA 222C2-4302, and to the Ofice of Managemem and Budge:. Papenwork Reduction Project 10704-0188). Washingion, DC 20503.

\begin{tabular}{|l|l|l|}
\hline 1. AGENCY USE ONLY (Leave blank) & 2. REPORT DATE & $\begin{array}{l}\text { 3. REPORT TYPE AND DATES COVERED } \\
\text { Interim ProgresS Report } 1-1-96 \text { to 12-31-96 }\end{array}$
\end{tabular}

4. TITLE AND SUBTITLE

5. FUNOING NUMBERS

Hydrogen Damage Susceptibility Assessment for High. Strengti DAAH04-96-1-0107

Steel Weldments through Advanced Hydrogen Content Analysis

6. AUTHOR(S)

David L. Olson and Tom Wildeman

7. PERFORMING ORGANIZATION NAMES(S) AND ADDRESS(ES)

Center for Welding, Joining, and Coatings Research

Colorado School of Mines

Golden, Colorado 80401-1887

9. SPONSORING / MONTORING AGENCY NAME(S) AND ADDRESS(ES)

U.S. Amy Research Office

P.O. Box 12211

Research Triangle Park, NC 27709-2211

8. PERFORMING ORGANIZATION REPORT NUMBER

\section{SUPPLEMENTARY NOTES}

The views, opinions and/or findings contained in this report are those of the author(s) and should not be construed as an official Department of the Army position, policy or decision, unless so designated by other documentation.

12a. DISTRIBUTION/AVAILABILITY STATEMENT

12 D. DISTRIBUTION CODE

Approved for public release; distribution unlimited.

13. ABSTRACT (Maximum 200 word's)

1

There is a growing concern that the hydrogen distribution across a high strength steel weldment is an important factor for cold cracking. A concem that becomes more significant with increasing strength levels and lower acceptable hydrogen concentrations. Depending on the hardenability of the base metal (heat affected zone) and the weld metal, these two regions may undergo austenite decomposition, more specifically martensite transformation, at different times. As a result of the earlier or later transformation of the weld metal (compared with the heat affected zone), the hydrogen may accumulate in the weld metal or in the heat affected zone. This behavior will lead to decreased or increased hydrogen damage susceptibility of the two regions and influence the location of the weldment most susceptible to cracking. This project will develop a detection practice including laser ablation and laser induced breakdown spectroscopy (LIBS) to determine the hydrogen distribution across the weld metal. 


\section{REPORT DOCUMENTATION PAGE (SF298)}

(Continuation Shcet)

1. List of Manuscript and Journal References

None, this period has been used for equipment development and preliminary

experimentation.

2. Scientific Personnel and Honors/Awards/Degrees Granted

David L. Olson - Principal Investigator

1996 AWS William Spraragen Memorial Award

Tom Wildeman - Co-Principal Investigator

David Smith - PhD. Student

\section{Report of Inventions}

-None-

\section{Scientific Progress and Accomplishments}

The hydrogen distribution in high strength steel weldments is of fundamental importance in understanding the role of hydrogen in cold cracking. The location of the hydrogen relative to the areas of the weld determines where such cracking will occur. This information becomes even more desirable where high strength steels are concerned because of their increased susceptibility to even low concentrations. The purpose of this research project is to develop a technique for characterizing total hydrogen distributions in steel welds and quantitation of hydrogen using various analytical methods. In the future it will be necessary to know both the weld diffusible hydrogen content as well as hydrogen distribution across the weldment. 
Preliminary searches indicated numerous possibilities for methods of detection including photoacoustic spectroscopy, gas chromatography, and laser induced breakdown spectroscopy (LIBS). Investigation using LIBS was begun on low carbon steel welds using the equipment at Los Alamos National Laboratory. Initial results are promising and show characteristic hydrogen spikes in the heat affected zone (HAZ) just adjacent to the weld fusion line. Further analyses need to address standardization of the analytical instrument for hydrogen and the fabrication of suitable standards using cathodic and atmospheric charging techniques. Additional samples are being analyzed to observe the effect of hydrogen traps such as titanium, neodymium and vanadium on the relative distributions. Further LIBS analyses will be performed as well as laser ablation coupled with gas chromatography utilizing a sensitive universal detector. Other methods may be attempted. The accurate determination of hydrogen in steel is feasible given the recent advances in instrumentation and analytical technology. After a technique has been selected, a comprehensive study will be made to establish a procedure to transfer this analytical practice to industry.

This project is an Augmentation activity to the ARO project (32823-MS) on High Strength Steel Weldment Reliability.

\section{Technology Transfer}

Some preliminary exploration of analytical techniques has been performed by CSM scientists at Los Alamos National Laboratory. 


\section{MODIFICATION OF PROPOSAL}

ARO PROPOSAL NUMBER: P-35387-MS-AAS

CONTRACTOR/GRANTEE: Colorado School of Mines

RESEARCH PROJECT TITLE: "Hydrogen Damage Susceptibility Assessment for High

Strength Steel Weldments Through Advanced Hydrogen Content Analysis"

PRINCIPAL INVESTIGATOR(S): Dr. David L. Olson

GENERAL: The Army Research Office (ARO) will processes all AASERT proposals in accordance with the procedures set forth in the FY 1996 DoD Broad Agency Announcement on Augmentation Awards for Science and Engineering Training. This AASERT proposal is directly related and relevant to the ongoing Army sponsored research under grant DAAH04-94-G-0281. The return of this modification will evidence that you have no objection to this method of processing your proposal.

APPLICABILITY OF INFORMATION: The paragraphs contained in the ensuing pages of this attachment request information needed for award of the above research project. Certain paragraphs may not be applicable to the specific award under consideration. Such paragraphs are rendered not applicable by use of a stamp marked "Information Not Required."

REPRESENTATIONS AND CERTIFICATIONS AND OTHER STATEMENTS: Please provide the following (if checked):

() Certification Page (ARO Form 95)

(X) Certification Page (ARO Form 95A)

() Representations and Certifications (ARO Form 53)

() Equipment Acquisition Statement (ARO Form 72)

() Representations and Certifications (DD Form 2222-1 and Supplement)

() Requirement for Certification of Procurement Integrity

() Requirement for Certification of Procurement Integrity - Modification

() Certificate of Indirect Cost Rate

SPECIAL CONSIDERATIONS: Special considerations, if any, which you must consider in the modification of your proposal are listed below:

1. Please provide a copy of your most current rate agreement.

2. Please revise your budget for an amount not-to-exceed $\$ 147,514$.

3. Please delete equipment purchases. Funds are not provided to purchase nonexpendable equipment or research instrumentation.

\section{ATTACHMENTS:}

ARO Form 56 - Instruction for Preparation of Budget

Standard Form 1411

ARO Form 57

(D.niment 


\section{AUTHOR APPLICATION FORM \\ 79th Annual AWS Convention, Detroit, Michigan, April 27-30, 1998}

Please use typewriter or word processor to complete both front and back of this form. This completed form is to accompany the 300-500 word summary described on the back.

Author's Name Rodney D. Smith II_Check how addressed: Dr. O Other

Title or position_Company or Organization Coloraco School of Mines

Mailing address_Center for Welding and Joining Research Chauvenet Hall

City State COZip/Postal Code 80401 Country _- USA

Area/Country Code 303 Telephone 384-2174 FAX 273-3629 e-mail address rsmith@mines.e du

Por jolnt authors, give, names and FULL MAILING addresses of other authors (list separately if necessary):

Name Deb
Title or position Preferew Company or Organization
Mailing address.

City _ State__ Country

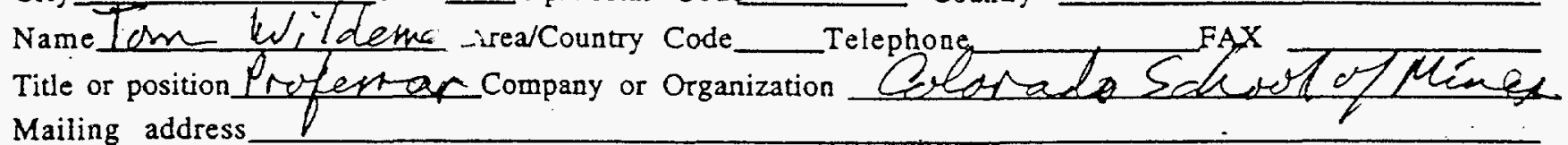

Mailing address

City State___ Zip/Postal Code

Country

PROPOSED TTTLE (10 words or less): A New Method for Determining Hydrogen Distribution in Welded Steel

Please check appropriate choice:

Y Research-Oriensed - new science or new research. This paper presents new, unpublished work in science or engincering in joining or allied processes.

- Applied Technology - new or unique application. This paper applies known principles of joining science or engineering in a unique, unpublishod application.

- Education - welding education-related topic. For, about, or pertaining to welding educators and trainers at all levels, their methods, and their successes.

is this paper an original contribution?

Is this paper a progress report?

Is this paper a review?

Is this paper a tutorial?

What are the welding process(es) used?

What are the materials used?

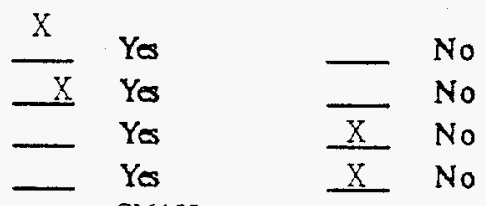

The main emphasis is more

The industries this paper most applies to are

HSLA steels GMAW

\section{Q process oriented 9 materials oriented}

Welding Industry, Ship Building

\section{KEY WORDS:}

Please rank the top four in order of importance (i.e., 1 = most important; 2 = second most important, etc.):

GTAW
4 GMAW
SMAW
SAW
PAW
FCAW
ESW
EBW
LBW
Resistance Welding
Forge Welding
Friction Welding
Diffusion Welding
Brazing/Soldering
Burfacing/Cladding

Hardfacing
Thermal Spraying
C-Mn Steels
Cr-Mo Steels
- High-Strength Steeis
Stainless Steels
Al-Alloys
Ni-Alloys
Ni-Alloys
Cu-Alloys
Codvanced Materials
- Polymeric Materials
Ceramics
Consumables/Fluxes
Celdability Testing

Piping/Tubing

Pressure Vessels

Weld Process Simulation

2 Process Control/Monitoring

Weld Design Advisors

— Numerical Anatysis

- Residual Stress/Distortion

- Fracture/Fatigue

- Automation

Robotics

- Sensors

- Arc Physics

Corrosion

NDE

_t Other H Embrittlement 
Author(s) of Proposed Paper.

Paper Tule: A Vow Wethod for Determining Hvdrogen Distribution in Welded Steel

\section{INTENDED AUDIENCE: (please check)}

D) Technical/Research-Oriented (review by Technical Papers Committee)

a Welding Education-Oriented (review by Education Committee)

a Industrially Oriented (review by Commercial Papers Subcommittee)

\section{GUWELINES FOR SUMMARY:}

\section{TECHNICAL PAPERS}

Each summary for a technical paper should be divided into four main sections:

* Introduction/Background Section (100 words max)

"Why the work was done," "How it relates to previous work done in the field"

* Procedure Section (100 words max)

Detailed (data base) description of approach and why this approach was taken

* Results and Discussion Section (200-300 words)

Detailed description of results with emphasis on

- what was found

- why the results are "new" or original

* why the results are of value

- Conclusions Section (100 words max)

Summary of main conclusions and recommendations for continuing work

\section{OTHER PAPERS (INCLUDING TUTORIALS)}

Summaries for other types of papers should be divided into two main sections:

* Introduction/Background Section (400 words max)

This section should begin with a description of why a paper or tutorial in this field is of value to the welding community, highlighting specific communities (if appropriate) for which this work is targeted. Once this bas been established, the author should describe key work in this field including a brief description of the results obtained and the conchusions drawn for each referesce (if appropriate) and provide the audience with an integration of these separate activities into a "continuum."

* Conclusion Section (100 words max)

This section should reiterate the key areas of value for this paper and provide guidance on the usage of this information - how and by whom.

- Type, donble spaced, using a 10-pitch element or 10 point font, a summary of not less than 300 but not more than 500 words. Please attach to this completed form and return to the address below.

- Be sure to give enough information to enable the review committee to get a clear idea of the content of the proposed paper. Please remember your intended audience. Technical papers will be judged on technical merit. A paper should net emphasize product names; use generic terms after the first mention of a trade-named product.

- Application Form and Summary MUST be postmarked no later than June 30, 1997 to ensure consideration for inclusion in the Professional Program of the 79th Annual AWS Convention in Detroit.

- Applications may also be submitted electronically (fretwell amweld.org) or by fax (305-442-7451), if followed by a mailed copy of the original application and summary to the address shown below.

\section{PRESENTATION AND PUBLICATION OF PAPERS:}

- Has material in this paper ever been previously published or presented in a meeting?

No No Yes When and Where?

- You have the option of submitting your completed manuscript either prior to presentation (before April 1, 1998) or waiting until after the convention (July 1,1998 ) if you would prefer to wait in order to incorporate points brought out during the discussion portion of your presentation Please submit your paper accordingly.

- Papers accepted for presentation become the property of the Society with original publication rights assigned to the Welding Journal.

Author's Signature
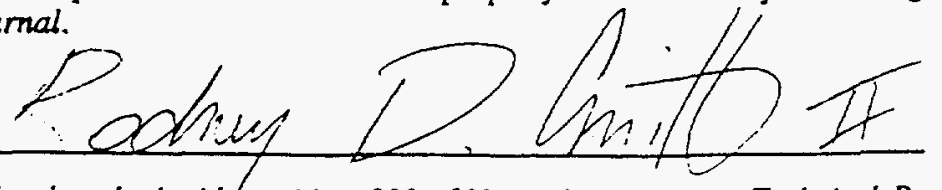

Date

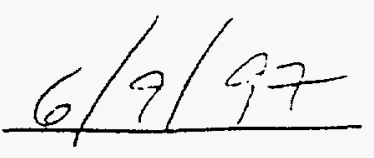

Retum this form, completed on both sides, with a 300-500 word summary to Techrical Papers Editor, AWS Headauarters, 550 N. W. LeJeune Road, Miami, FL 33126. MUST BE POSTMARKED NO LATER THAN JUNE 30, 1997. 
Public reporting burden lox this collection of information is estimsted lo average i hou? pes response. induding the time for reviewing instructions. searching existing data sources. gathering and maintaining the data noeded. and completing and reviewing the colfection of information. Send comment regarding this burcen estimates or any other aspect of this

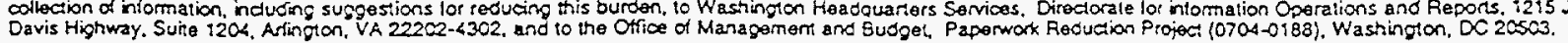

\begin{tabular}{l|l|l|}
\hline 1. AGENCY USE ONLY (Leave blank) & 2. REPORT DATE & 3. REPORT TYPE AND DATES COVERED
\end{tabular} Interim Progress Report $1-1-96$ to $12-31-96$

4. TITLE ANO SUSTITLE

5. FUNOING NUMBERS

Hydrogen Damage Susceptibility Assessment for High."Strength

DAAHO4-96-I-0107

Steel Weldments through Advanced Hydrogen Content Analysis

\section{AUTHOR(S)}

David L. Olson and Tom Wildeman

7. PERFORMING ORGANIZATION NAMES(S) AND AODRESS(ES)

Center for Welding, Joining, and Coatings Research

Colorado School of Mines

Golden, Colorado 80401-1887

9. SPONSORING / MONTTORING AGENCY NAME(S) AND ADDRESS(ES)

U.S. Army Research Office

P.O. Box 12211

Research Triangle Park, NC 27709-2211

\section{SUPPLEMENTARY NOTES}

The views, opinions and/or findings contained in this report are those of the author(s) and should not be construed as an official Department of the Army position, policy or decision, unless so designated by other documentation.

12a. DISTRIBUTION/AVAILABILITY STATEMENT

12 b. DISTRIBUTION CODE

Approved for public release; öistribution unlimited.

13. ABSTRACT (Maximum 200 words)

8. PERFORMING ORGANIZATION REPORT NUMBER
10. SPONSORING / MONITORING AGENCY REPORT NUMBER $P-35387-M S-A A S$

There is a growing concern that the hydrogen distribution across a high strength steel weldment is an important factor for cold cracking. A concem that becomes more significant with increasing strength levels and lower acceptable hydrogen concentrations. Depending on the hardenability of the base metal (heat affected zone) and the weld metal, these two regions may undergo austenite decomposition, more specifically martensite transformation, at different times. As a result of the earlier or later transformation of the weld metal (compared with the heat affected zone), the hydrogen may accumulate in the weld metal or in the heat affected zone. This behavior will lead to decreased or increased hydrogen damage susceptibility of the two regions and influence the location of the weldment most susceptible to cracking. This project will develop a detection practice including laser ablation and laser induced breakdown spectroscopy (LBS) to determine the hydrogen distribution across the weld metal. 


\section{List of Manuscript and Journal References}

None, this period has been used for equipment development and preliminary experimentation.

\section{Scientific Personnel and Honors/Awards/Degrees Granted}

David L. Olson - Principal Investigator

$$
1996 \text { AWS William Spraragen Memorial Award }
$$

Tom Wilderı.s - Co-Principal Investigator

David Smith - PhD. Student

\section{Report of Inventions}

\section{-None-}

\section{Scientific Progress and Accomplishments}

The hydrogen distribution in high strength steel weldments is of fundamental importance in understanding the role of hydrogen in cold cracking. The location of the hydrogen relative to the areas of the weld determines where such cracking will occur. This information becomes even more desirable where high strength steels are concerned because of their increased susceptibility to even low concentrations. The purpose of this research project is to develop a technique for characterizing total hydrogen distributions in steel welds and quantitation of hydrogen using various analytical methods. In the future it will be necessary to know both the weld diffusible hydrogen content as well as hydrogen distribution across the weldment. 


\section{REPORT DOCUMENTATION PAGE (SF298)}

(Continuation Shect)

Preliminary searches indicated numerous possibilities for methods of detection including photoacoustic spectroscopy, gas chromatography, and laser induced breakdown spectroscopy (LIBS). Investigation using LIBS was begun on low carbon steel welds using the equipment at Los Alamos National Laboratory. Initial results are promising and show characteristic hydrogen spikes in the heat affected zone (HAZ) just adjacent to the weld fusion line. Further analyses need to address standardization of the analytical instrument for hydrogen and the fabrication of suitable standards using cathodic and atmospheric charging tech iues. Additional samples are being analyzed to observe th. effect of hydrogen traps such as titanium, neodymium and vanadium on the relative distributions. Further LIBS analyses will be performed as well as laser ablation coupled with gas chromatography utilizing a sensitive universal detector. Other methods may be attempted. The accurate determination of hydrogen in steel is feasible given the recent advances in instrumentation and analytical technology. After a technique has been selected, a comprehensive study will be made to establish a procedure to transfer this analytical practice to industry.

This project is an Augmentation activity to the ARO project (32823-MS) on High Strength Steel Weldment Reliability.

\section{Technology Transfer}

Some preliminary exploration of analytical techniques has been performed by CSM scientists at Los Alamos National Laboratory. 


\section{MODIFICATION OF PROPOSAL}

ARO PROPOSAL NUMBER: P-35387-MS-AAS

CONTRACTOR/GRANTEE: Colorado School of Mines

RESEARCH PROJECT TITLE: "Hydrogen Damage Susceptibility Assessment for High

Strength Steel Weldments Through Advanced Hydrogen Content Analysis"

PRINCIPAL INVESTIGATOR(S): Dr. David L. Olson

GENERAL: The Army Research Office (ARO) will processes all AASERT proposals in accordance with the procedures set forth in the FY 1996 DoD Broad Agency Announcement on Augmentation Awards for Science and Engineering Training. This AASERT proposal is directly related and relevant to the ongoing Army sponsored research under grant DAAH04-94-G-0281. The retu.n of this modification will evidence that you have no objection to this method of processing your proposal.

APPLICABILITY OF INFORMATION: The paragraphs contained in the ensuing pages of this attachment request information needed for award of the above research project. Certain paragraphs may not be applicable to the specific award under consideration. Such paragraphs are rendered not applicable by use of a stamp marked "Information Not Required."

REPRESENTATIONS AND CERTIFICATIONS AND OTHER STATEMENTS: Please provide the following (if checked):

() Certification Page (ARO Form 95)

(X) Certification Page (ARO Form 95A)

() Representations and Certifications (ARO Form 53)

() Equipment Acquisition Statement (ARO Form 72)

() Representations and Certifications (DD Form 2222-1 and Supplement)

( ) Requirement for Certification of Procurement Integrity

() Requirement for Certification of Procurement Integrity - Modification

() Certificate of Indirect Cost Rate

SPECLAL CONSIDERATIONS: Special considerations, if any, which you must consider in the modification of your proposal are listed below:

1. Please provide a copy of your most current rate agreement.

2. Please revise your budget for an amount not-to-exceed $\$ 147,514$.

3. Please delete equipment purchases. Funds are not provided to purchase nonexpendable equipment or research instrumentation.

\section{ATTACHMENTS:}

ARO Form 56 - Instruction for Preparation of Budget

Standard Form 1411

ARO Form 57

in....... 